\title{
Synthesis of New Bioinorganic Systems Based on Nitrilium Derivatives of closo-Decaborate Anion and meso-Arylporphyrins with Pendant Amino Groups
}

Artem V. Ezhov, ${ }^{a}$ Fedor Yu. Vyal'ba, ${ }^{a}$ Ilya N. Kluykin, ${ }^{\mathrm{b}}{ }$ Kseniya A. Zhdanova, ${ }^{\mathrm{a} 1}$ Natal'ya A. Bragina, ${ }^{a}$ Andrey P. Zhdanov, ${ }^{\mathrm{b}}$ Konstantin Yu. Zhizhin, ${ }^{\mathrm{b}}$

Andrey F. Mironov, ${ }^{a}$ and Nikolay T. Kuznetsov ${ }^{\mathrm{b}}$

Dedicated to Academician Aslan Yu. Tsivadze on the ocassion of his 75th Birthday \author{
Russian Federation \\ @1E-mail: zhdanova_k@mirea.ru \\ ${ }^{\circledR 2}$ E-mail: zhizhin@igic.ras.ru
}

${ }^{a}$ Moscow Technological University (MITHT), 119571 Moscow, Russian Federation

${ }^{\mathrm{b}}$ N.S. Kournakov Institute of General and Inorganic Chemistry of Russian Academy of Sciences (IGIC RAS), 119991 Moscow,

\begin{abstract}
In this work we elaborated an approach to the synthesis of meso-arylporphyrin with pendant amino groups. This approach is based on the preliminary functionalization of 4-(4-bromobutyloxy)benzaldehyde by potassium phthalimide, its condensation with pyrrole and removing the protecting phthalimide group. New boron-porphyrin conjugates were synthesized based on final aminoporphyrin and closo-decaborate anion $\left[\mathrm{B}_{10} \mathrm{H}_{10}\right]^{2-}$. New conjugates were obtained using microwave synthesis which reduced reaction time in 2 fold. Spectral properties of the conjugates were evaluated based on electron absorption spectra and steady-state fluorescence.
\end{abstract}

Keywords: meso-Arylporphyrins, closo-decaborate anions, microwave synthesis.

\section{Синтез новых бионеорганических систем на основе нитрилиевых производных кАозо-Аекаборатного аниона и мезо-арилпорфиринов с пендантными аминогруппами}

\author{
А. В. Ежов, ${ }^{\text {a }}$ Ф. Ю. Вяльба, ${ }^{a}$ И. Н. Клюкин, ${ }^{\text {b }}$ К. А. Жданова, ${ }_{1} @ 1$ Н. А. Брагина, ${ }^{a}$ \\ А. П. ЖАанов, ${ }^{b}$ К. Ю. Жижин, ${ }^{\text {b@2 } 2}$ А. Ф. Миронов, ${ }^{a}$ Н. Т. Кузнецов ${ }^{b}$
}

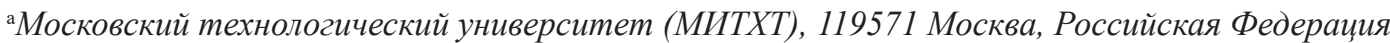

${ }^{\mathrm{b}}$ Институт общей и неорганической химии им. Н.С. Курнакова РАН, 119991 Москва, Россия

@1E-mail: zhdanovakk@mirea.ru

${ }^{\circledR 2}$ E-mail: zhizhin@igic.ras.ru
}

\begin{abstract}
Был разработан подход к синтезу амфифильных мезо-арилпорфиринов с пендантными аминогруппами. Метод основан на предварительной функционализачии 4-(4-бромбутилокси)бензальдегида фталимидом калия, его последующей монопиррольной конденсации и снятии защчтной группь. Были синтезированы новые борпорфириновые конъюгаты на основе полученного аминопорфирина и клозо-декаборатного аниона $\left[B_{10} H_{10}\right]^{2-}$. Новые конъюгаты были также получены с использованием микроволнового синтеза, что уменьшило время реакиии в 2 раза. Спектральные свойства конъюгатов были исследованы с помощью методов электронной спектроскопии и флуоресценции.
\end{abstract}

Ключевые слова: мезо-Арилпорфирины, анион клозо-декабората, микроволновый синтез. 


\section{Introduction}

Photodynamic therapy (PDT) and boron neutron capture therapy $(\mathrm{BNCT})$ are promising methods for treating tumors. ${ }^{[1]}$ BNCT is used in case of difficult-to-treat cancers particullary brain tumors as malignant glioma with poor prognosis. BNCT and PDT both are bimodal therapies, the individual components are non-toxic in isolation but tumoricidal in combination. ${ }^{[2]}$ For the BNCT purposes it is necessary to create boron-containing drugs. In clinical practice, sodium mercapto-closo-dodecaborate (BSH) and boronophenylalanine (BPA) - boron containing drugs are used. BSH and BPA have demonstrated low toxicity and efficacy in BNCT clinical trials. Nevertheless improved boron delivery agents with higher tumor selectivity and ability to deliver therapeutic amounts of boron $(>20 \mu \mathrm{g} / \mathrm{g}$ tumor) to the target tumors with low systemic toxicity have been the focus of intense research. ${ }^{[3]}$ So-called third-generation boron delivery agents include boronated amino acids, proteins, antibodies, nucleosides, sugars, lipids, liposomes, nanoparticles, and porphyrin derivatives. ${ }^{[4,5]}$ Among these, boronated porphyrins have emerged as promising dual sensitizers for both PDT and BNCT by virtue of the following characteristics: tumor affinity by the porphyrin ring; ease of synthesis with a high boron content; low cytotoxicity in dark conditions; and desirable photophysical properties, including strong light absorption in the visible and near infrared regions, the ability to generate singlet oxygen upon light activation and fluorescence properties. ${ }^{[2]}$

Recently we have elaborated approaches to the synthesis of boron-porphyrin conjugates by the reaction of nucleophilic addition in which porphyrins with amino groups react with nitrilium derivative of closo-decaborate anion $\left[2-\mathrm{B}_{10} \mathrm{H}_{9} \mathrm{~N} \equiv \mathrm{CMe}\right]^{-[6,7]}$ In this paper, we proposed synthesis of amphiphilic porphyrins with pendant functional amino groups and anions $\left[\mathrm{B}_{10} \mathrm{H}_{10}\right]^{2-}$. The preparation of new bioinorganic conjugates with various attachment types of boron clusters to the porphyrin moiety can provide the possibility of varying the degree of final products amphiphilicity (by changing the length of the alkoxy radicals and the spacer) and the possibility of the formation of additional supramolecular interactions.

\section{Experimental}

All chemicals were obtained commercially and used as received unless otherwise noted. Pyrrole was purified by vacuum distillation; dichloromethane, hexane were dried by standard methods prior to use. Column chromatography was performed on silica gel G 60 (Merck Inc, 40-70 mesh). TLC was performed on pre-coated silica gel glass plates (silica gel 60, F-254, thickness $0.25 \mathrm{~mm}$ ) by Merck Inc. 4-Hydroxybenzaldehyde, potassium phthalimide, boron trifluoride, DBU were purchased from SigmaAldrich and used without further purification. $p$-(Hexadecyloxy) benzaldehyde was purchased by approach. ${ }^{[8]}$ Microwave synthesis was carried out using Minotavr-2 installation (Russia). UV-Vis spectra were recorded on TermoSpectronic Helios Alpha spectrophotometer in quartz cells of $1 \mathrm{~cm}$ thickness. IR spectra of prepared compounds were recorded using an Infralyum FT 02 Fourier transform spectrometer (Lumex Instruments Research and Production Company) in the region of $4000-300 \mathrm{~cm}^{-1}$ with a resolution of $1 \mathrm{~cm}^{-1}$. Samples were prepared in Nujol (Aldrich) or in $\mathrm{KBr}$ pel- lets. NMR $\left({ }^{1} \mathrm{H},{ }^{13} \mathrm{C},{ }^{11} \mathrm{~B}\right)$ spectra of solutions of studied compounds in $\mathrm{CDCl}_{3}$ or $\mathrm{CD}_{2} \mathrm{Cl}_{2}$ were performed on a Bruker Advance II 300 spectrometer operating at 300.3, 96.32, and $75.49 \mathrm{MHz}$, respectively, using internal deuterium lock. Tetramethylsilane and boron trifluoride etherate were used as external references. Mass-spectra were registered on «Ultraflex» (MALDI-TOF, matrix - DHB) and Bruker micrOTOF spectrometer (ESI-MS, THF as solvent). Elemental analysis for carbon, nitrogen, and hydrogen was carried out using a Carlo Erba CHNS3 FA 1108 Elemental Analyzer. Analysis of boron content was conducted by using ICP MS on an iCAP 6300 Duo inductively coupled plasma-atomic emission spectrometer at the Shared Knowledge Center "Scientific Research Analytical Center FSUE IREA National Research Center Kurchatov Institute". p-(4-Bromobutyloxy)benzaldehyde (1). To the solution of $2 \mathrm{~g}$ $(16.3 \mathrm{mmol})$ of 4-hydroxybenzaldehyde in $30 \mathrm{ml}$ of THF a solution of 1,4-dibromobutane (3.55 g, $16 \mathrm{mmol})$ and DBU (2.74 g, 18 $\mathrm{mmol}$ ) in $10 \mathrm{ml}$ of THF was added. Reaction mixture was refluxed for $5 \mathrm{~h}$. Reaction mass was concentrated in vacuum and extracted in system chloroform $/ \mathrm{H}_{2} \mathrm{O}$, organic part was extracted again and purified by column chromatography on silica gel G60 (eluent chloroform:hexane $=3: 1$ ) and dried in vacuum under $\mathrm{P}_{2} \mathrm{O}_{5}$. Yield: $2.74 \mathrm{~g}(65 \%) . R_{f}=0.17$ (chloroform:hexane $\left.=3: 1\right) . I R \vee \mathrm{cm}^{-1}: 1676$ (CHO), 1275, $1033(\mathrm{C}-\mathrm{O}) .{ }^{1} \mathrm{H}$ NMR $\left(\mathrm{CDCl}_{3}\right) \delta_{\mathrm{H}}$ ppm: $9.81(\mathrm{~s}, 1 \mathrm{H}$, $\mathrm{CHO}), 7.76(\mathrm{~d}, 2 \mathrm{H}, o-\mathrm{Ph}), 6.92(\mathrm{~d}, 2 \mathrm{H}, m-\mathrm{Ph}), 4.02\left(\mathrm{t}, 2 \mathrm{H}, \mathrm{OCH}_{2}\right)$, 3.42 (t, 2H, $\left.\mathrm{CH}_{2} \mathrm{Br}\right), 1.96$ (m, 4H, $\left.\mathrm{OCH}_{2} \mathrm{CH}_{2} \mathrm{CH}_{2} \mathrm{CH}_{2} \mathrm{Br}\right)$.

p-(4-Phthalimidebutyloxy)benzaldehyde (2). To the solution of $0.8 \mathrm{~g}$ ( $3.1 \mathrm{mmol})$ of benzaldehyde 1 in $20 \mathrm{ml}$ of DMF $0.8 \mathrm{~g}$ $(4.3 \mathrm{mmol})$ of potassium phthalimide was added. Reaction mixture was stirred at $80{ }^{\circ} \mathrm{C}$ in argon flow during $5 \mathrm{~h}$, then it was extracted in system chloroform $/ \mathrm{H}_{2} \mathrm{O}$, organic phase was concentrated and purified by column chromatography on silica gel G60, eluent chloroform:hexane $=3: 1$. Product was dried in vacuum under $\mathrm{P}_{2} \mathrm{O}_{5}$. Yield $0.93 \mathrm{~g}(92 \%) . R_{f}=0.30$ (hexane:chloroform $\left.=1: 4\right) .{ }^{1} \mathrm{H}$ NMR $\left(\mathrm{CDCl}_{3}\right) \delta_{\mathrm{H}}$ ppm: $9.82(\mathrm{~s}, 1 \mathrm{H}, \mathrm{CHO}), 7.78(\mathrm{~m}, 4 \mathrm{H}, o-\mathrm{Ph}+4,7-\mathrm{Pht})$, 7.67 (m, 2H, 5,6-Pht), 6.94 (d, 2H, $m$-Ph), 4.04 (t, 2H, OCH ${ }_{2}$ ), 3.74 (t, $2 \mathrm{H}, \mathrm{CH}_{2} \mathrm{Pht}$ ), 2.10 (m, 4H, $\mathrm{OCH}_{2} \mathrm{CH}_{2} \mathrm{CH}_{2} \mathrm{CH}_{2} \mathrm{Pht}$ ).

p-(Hexadecyloxy)benzaldehyde (3). To the solution of $2 \mathrm{~g}$ (16.3 mmol) of 4-hydroxybenzaldehyde in $30 \mathrm{ml}$ of THF a solution of 1-bromohexadecane ( $6 \mathrm{~g}, 19.7 \mathrm{mmol})$ and DBU (2.74 g, 18 $\mathrm{mmol}$ ) in $10 \mathrm{ml}$ THF was added. Reaction mixture was refluxed for $5 \mathrm{~h}$. Reaction mass was concentrated in vacuum and extracted in system chloroform $/ \mathrm{H}_{2} \mathrm{O}$, organic part was extracted again and purified by column chromatography on silica gel G60 (eluent chloroform:hexane $=4: 1$ ) and dried in vacuum under $\mathrm{P}_{2} \mathrm{O}_{5}$. Yield: $2.74 \mathrm{~g}(85 \%) . R_{f}=0.29$ (hexane:chloroform $\left.=1: 3\right) .{ }^{1} \mathrm{H}$ NMR $\left(\mathrm{CDCl}_{3}\right) \delta_{\mathrm{H}} \mathrm{ppm:} 9.81(\mathrm{~s}, 1 \mathrm{H}, \mathrm{CHO}), 7.76(\mathrm{~d}, 2 \mathrm{H}, o-\mathrm{Ph}), 6.92(\mathrm{~d}$, $2 \mathrm{H}, m-\mathrm{Ph}), 4.03$ (t, $\left.2 \mathrm{H}, \mathrm{OCH}_{2}\right), 1.81\left(\mathrm{~m}, 2 \mathrm{H}, \mathrm{OCH}_{2} \mathrm{CH}_{2}\right), 1.49-1.19$ (m, 26H, $\left.\left(\mathrm{CH}_{2}\right)_{13}\right), 0.95\left(\mathrm{t}, 3 \mathrm{H}, \mathrm{CH}_{3}\right)$.

5,10,15-(4-Hexadecyloxy)phenyl-20-(4-phthalimidebutyloxy)

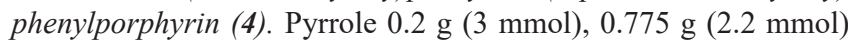
$p$-(hexadecyloxy)benzaldehyde, $0.241 \mathrm{~g}(0.7 \mathrm{mmol})$ benzaldehyde 2 were dissolved in dichloromethane $(200 \mathrm{ml})$, mixture was stirred in argon flow during $5 \mathrm{~min}$. To the reaction mass $0.5 \mathrm{ml}$ of ethanol and $35 \mu 1$ of boron trifluoride were added and stirred at room temperature in argon flow without light irradiation during $30 \mathrm{~min}$, then 0.5 $\mathrm{g}$ of DDQ was added and stirred overnight. Reaction mass was concentrated on rotary evaporator and purified by column chromatography on silica gel G60, eluent - dichloromethane:hexane $=4: 1$. Product was dried in vacuum under $\mathrm{P}_{2} \mathrm{O}_{5}$. Yield: $0.15 \mathrm{~g}(13 \%) . R$ $=0.34$ (hexane:dichloromethane $=1: 4)$. UV-Vis $\left(\mathrm{CH}_{2} \mathrm{Cl}_{2}\right) \lambda_{\text {max }} \mathrm{nm}$ : 421, 519, 556, 593, 651 (1:0.15:0.11:0.07:0.03). ${ }^{1} \mathrm{H}$ NMR $\left(\mathrm{CDCl}_{3}\right)$ $\delta_{\mathrm{H}}$ ppm: 8.89 (br.s, $8 \mathrm{H}$, pyrrole), $8.13(\mathrm{~d}, 8 \mathrm{H}, o-\mathrm{Ph}), 7.91(\mathrm{~m}, 2 \mathrm{H}$, 4.7-Pht), 7.73 (m, 2H, 5,6-Pht), 7.29 (m, 8H, m-Ph), 4.04 (t, 8H, $\left.\mathrm{OCH}_{2}\right), 3.75$ (t, 2H, CH $\mathrm{Pht}$ ), 2.10 (m, 4H, $\mathrm{OCH}_{2} \mathrm{CH}_{2} \mathrm{CH}_{2} \mathrm{CH}_{2} \mathrm{Pht}$ ), $1.83\left(\mathrm{~m}, 6 \mathrm{H}, \mathrm{OCH}_{2} \mathrm{CH}_{2}\right), 1.60-1.20\left(\mathrm{~m}, 78 \mathrm{H},\left(\mathrm{CH}_{2}\right)_{13}\right), 0.92(\mathrm{t}, 9 \mathrm{H}$, $\mathrm{CH}_{3}$ ), 2.67 (br.s, $1,5 \mathrm{H}, \mathrm{NH}$ ).

5,10,15-(4-Hexadecyloxy)phenyl-20-(4-aminobutyloxy) phenylporphyrin (5). $100 \mathrm{mg}(0.6 \mathrm{mmol})$ of porphyrin 4 was dis- 
solved in $100 \mathrm{ml}$ of dioxane, $15 \mathrm{ml}$ of ethanol and $15 \mathrm{ml}$ of water were added and stirred at $60{ }^{\circ} \mathrm{C}$ until the complete dissolvation. Then, $15 \mathrm{ml}$ of $5 \mathrm{~N} \mathrm{NaOH}$ solution was slowly added and the reaction mixture was refluxed for an hour. The reaction mass was neutralized with sulfuric acid, concentrated on a rotary evaporator, after which $10 \mathrm{ml}$ of $70 \%$ sulfuric acid was added, treated in an ultrasonic bath for several minutes and refluxed for 4 hours. The product was extracted into a dichloromethane-water system with sodium bicarbonate neutralization and purified by column chromatography on silica gel G60, eluent - dichloromethane:ethylacetate $=9: 1$. Product was dried in vacuum under $\mathrm{P}_{2} \mathrm{O}_{5}$. Yield: $0.62 \mathrm{~g}(68 \%) . R_{f}=0.19$ (hexane:dichloromethane $=1: 4)$. UV-Vis $\left(\mathrm{CH}_{2} \mathrm{Cl}_{2}\right) \lambda_{\text {max }}$ (lge) $\mathrm{nm}$ : 421 (4.61), 519 (3.94), 557 (3.81), 593 (3.42), 652 (3.39). ' $\mathrm{H}$ NMR $\left(\mathrm{CDCl}_{3}\right) \delta_{\mathrm{H}}$ ppm: 8.89 (br.s, $8 \mathrm{H}$, pyrrole), $8.13(\mathrm{~d}, 8 \mathrm{H}, o-\mathrm{Ph}), 7.29$ $(\mathrm{m}, 8 \mathrm{H}, m-\mathrm{Ph}), 4.04\left(\mathrm{t}, 8 \mathrm{H}, \mathrm{OCH}_{2}\right), 3,09\left(\mathrm{~m}, 2 \mathrm{H}, \mathrm{CH}_{2} \mathrm{NH}_{2}\right), 1.99(\mathrm{~m}$, $\left.4 \mathrm{H}, \mathrm{OCH}_{2} \mathrm{CH}_{2} \mathrm{CH}_{2} \mathrm{CH}_{2} \mathrm{NH}_{2}\right), 1.83\left(\mathrm{~m}, 6 \mathrm{H}, \mathrm{OCH}_{2} \mathrm{CH}_{2}\right), 1.60-1.20$ $\left(\mathrm{m}, 78 \mathrm{H},\left(\mathrm{CH}_{2}\right)_{13}\right), 0.92$ (t, $\left.9 \mathrm{H}, \mathrm{CH}_{3}\right),-2.67$ (br.s, $1,5 \mathrm{H}, \mathrm{NH}$ ).

2-(Ethylidineammonio)nonahydro-closo-decaborate (1-) tetrabutylammonium $\left(\mathrm{NBu}_{4}\right)\left[2-\mathrm{B}_{10} \mathrm{H}_{9}\left(\mathrm{NCCH}_{3}\right)\right](6)$ was prepared according to known procedures. ${ }^{[7]}$

2,7(6)-Bis(ethylidineammonio)-closo-decaborane (0) 2,7(6)$B_{10} \mathrm{H}_{8}\left(\mathrm{NCCH}_{3}\right)_{2}(7)$. A solution of $0.30 \mathrm{~g}(0.78 \mathrm{mmol})$ of $\mathrm{Cs}_{2} \mathrm{~B}_{10} \mathrm{H}_{10}$ in a mixture of $5 \mathrm{ml}$ of acetonitrile $\left(\mathrm{CH}_{3} \mathrm{CN}\right), 0.1 \mathrm{ml}$ of $\mathrm{CF}_{3} \mathrm{SO}_{3} \mathrm{H}$ was heated for 3 hours at $60{ }^{\circ} \mathrm{C}$ with stirring under an atmosphere of dry argon until gas ceased to be evolved. The reaction mass was neutralized with $\mathrm{Na}_{2} \mathrm{CO}_{3}$. Then, acetonitrile was concentrated on a rotary evaporator at $35^{\circ} \mathrm{C}$. The amorphous powder was solved in dichloromethane and $\mathrm{CF}_{3} \mathrm{SO}_{3} \mathrm{Cs}$ was filtered off. Product was dried in vacuum under $\mathrm{P}_{2} \mathrm{O}_{5}$. Yield: $0.13 \mathrm{~g}(85 \%)$. Found (\%): C 24.35, H 6.99, N 14.35, B 23.9. Anal. Calc. for $\mathrm{C}_{100} \mathrm{H}_{149} \mathrm{~B}_{10} \mathrm{~N}_{7} \mathrm{O}_{4}$, (476.5) (\%): C 24.23, H 7.11, N 14.12, B 24.2. IR (Nujol) $v \mathrm{~cm}^{-1}$ : $2495(\mathrm{BH}), 2345(\mathrm{CN}) 1104(\mathrm{~B}-\mathrm{B}-\mathrm{H}) .{ }^{11} \mathrm{~B}-\left\{{ }^{1} \mathrm{H}\right\} \mathrm{NMR}\left(\mathrm{CD}_{2} \mathrm{Cl}_{2}\right) \delta$ ppm: $1.6\left(\mathrm{~d}, 1 \mathrm{~B}, \mathrm{~B}_{\mathrm{ap}}\right), 0.4\left(\mathrm{~d}, 1 \mathrm{~B}, \mathrm{~B}_{\mathrm{ap}}\right),-18.5\left(\mathrm{~s}, 2 \mathrm{~B}, \mathrm{~B}_{\mathrm{sub}}\right),-25.4(\mathrm{~d}$, 3B), -26.8 (d, 2B), -28.6 (d, 1B). ${ }^{1} \mathrm{H}$ NMR $\left(\mathrm{CD}_{2} \mathrm{Cl}_{2}\right) \delta$ ppm: 0.60 $2.10\left(\mathrm{~m}, 8 \mathrm{H}, \mathrm{B}_{10} \mathrm{H}_{8}\right), 2.49\left(\mathrm{~s}, 4.2 \mathrm{H}, \mathrm{CH}_{3}, 2,7\right.$-regioisomer $\left.(70 \%)\right)$, $2.28\left(\mathrm{~s}, 1.8 \mathrm{H}, \mathrm{CH}_{3}, 2,6\right.$-regioisomer $\left.(30 \%)\right)$.

Synthesis of conjugate (8). A solution of $30 \mathrm{mg}(0.075 \mathrm{mmol})$ of 6 and $20 \mathrm{mg}(0.014 \mathrm{mmol})$ of compound 5 in $5 \mathrm{ml}$ of dichloroethane $\left(\mathrm{C}_{2} \mathrm{H}_{4} \mathrm{Cl}_{2}\right)$, was heated for 6 hours at $70{ }^{\circ} \mathrm{C}$ with stirring under an atmosphere of dry argon. Then, reaction mixture was concentrated on a rotary evaporator and product was purified by column chromatography on silica gel $\mathrm{G} 60$, eluent $-\mathrm{CH}_{2} \mathrm{Cl}_{2}: \mathrm{CH}_{3} \mathrm{CN}$ gradient from 5:1. Product was dried in vacuum under $\mathrm{P}_{2} \mathrm{O}_{5}$. Yield: $17.8 \mathrm{mg}(70 \%$ ). MS (ESI) $\mathrm{m} / \mathrm{z}: 1581.3638$ (A refers to the molecular weight of $\mathrm{C}_{98} \mathrm{H}_{147} \mathrm{~B}_{10} \mathrm{~N}_{6} \mathrm{O}_{4}$, calculated for $\{[\mathrm{A}]-$ \} 1581.3647). IR (Nujol) $v \mathrm{~cm}^{-1}: 2495$ (BH), 2345 (CN) 1104 (B-B-H). UV-Vis (THF) $\lambda_{\max }$ (lge) nm: 421 (4.63), 516 (3.97), 557 (3.84), 595 (3.46), 651 (3.44). ${ }^{11} \mathrm{~B}-\left\{{ }^{1} \mathrm{H}\right\}$ NMR $\left(\mathrm{CD}_{2} \mathrm{Cl}_{2}\right) \delta \mathrm{ppm}$ : $-0.7\left(\mathrm{~d}, 1 \mathrm{~B}, \mathrm{~B}_{\mathrm{ap}}\right),-7.9$ $\left(\mathrm{d}, 1 \mathrm{~B}, \mathrm{~B}_{\mathrm{ap}}\right),-18.6\left(\mathrm{~s}, 1 \mathrm{~B}, \mathrm{~B}_{\mathrm{sub}}\right),-27.4(\mathrm{~d}, 4 \mathrm{~B}),-30.6(\mathrm{~d}, 3 \mathrm{~B}) .{ }^{1} \mathrm{H}$ NMR $\left(\mathrm{CD}_{2} \mathrm{Cl}_{2}\right) \delta$ ppm: 0.60-2.10 (m, 9H, $\left.\mathrm{B}_{10} H_{9}\right), 10.78$ (br.s, $1 \mathrm{H}$, $\left.\mathrm{CH}_{2} \mathrm{NH}\right), 8.88$ (br.s, $8 \mathrm{H}$, pyrrole), $8.10(\mathrm{~d}, 8 \mathrm{H}, o-\mathrm{Ph}), 7.29(\mathrm{~m}, 8 \mathrm{H}$, $m$-Ph), 5.95 (br.s., $1 \mathrm{H}, \mathrm{NH}=\mathrm{C}), 4.26\left(\mathrm{t}, 8 \mathrm{H}, \mathrm{OCH}_{2}\right), 3.44(\mathrm{~m}, 2 \mathrm{H}$, $\left.\mathrm{CH}_{2} \mathrm{NH}\right), 3.10\left(\mathrm{~m}, 8 \mathrm{H}, \mathrm{NBu}_{4}\right), 2.23\left(\mathrm{~s} .3 \mathrm{H}, \mathrm{CH}_{3}\right), 1.99\left(\mathrm{~m}, 4 \mathrm{H}, \mathrm{OCH}_{2}\right.$ $\left.\mathrm{CH}_{2} \mathrm{CH}_{2} \mathrm{CH}_{2} \mathrm{NH}_{2}\right), 1.73\left(\mathrm{~m}, 6 \mathrm{H}, \mathrm{OCH}_{2} \mathrm{CH}_{2}\right), 1.59\left(\mathrm{~m}, 8 \mathrm{H}, \mathrm{NBu}_{4}\right)$, $1.60-1.20\left(\mathrm{~m}, 78 \mathrm{H},\left(\mathrm{CH}_{2}\right)_{13}\right), 1.36\left(\mathrm{~m}, 8 \mathrm{H}, \mathrm{NBu}_{4}\right), 0.96(\mathrm{~m}, 12 \mathrm{H}$, $\left.\mathrm{NBu}_{4}\right), 0.85$ (t, 9H, $\mathrm{CH}_{3}$ ), -2.76 (br.s, $2 \mathrm{H}, \mathrm{NH}$ ).

Synthesis of conjugate (9). A solution of $2.7 \mathrm{mg}(0.014 \mathrm{mmol})$ of 7 and $40 \mathrm{mg}(0.028 \mathrm{mmol})$ of compound 5 in $5 \mathrm{ml}$ of dichloroethane $\left(\mathrm{C}_{2} \mathrm{H}_{4} \mathrm{Cl}_{2}\right)$, was heated for 3 hours at $60{ }^{\circ} \mathrm{C}$ in the microwave system (Minotavr-2). Then, reaction mixture was concentrated on a rotary evaporator and product was purified by column chromatography on silica gel $\mathrm{G} 60$, eluent $-\mathrm{CH}_{2} \mathrm{Cl}_{2}: \mathrm{CH}_{3} \mathrm{CN}$ gradient from 5:1. Product was dried in vacuum under $\mathrm{P}_{2} \mathrm{O}_{5}$. Yield: $12.7 \mathrm{mg}(30$ \%). MS (ESI) $m / z$ : 2819.0831 (A refers to the molecular weight of $\mathrm{C}_{180} \mathrm{H}_{251} \mathrm{~B}_{10} \mathrm{~N}_{12} \mathrm{O}_{8}$, calculated for $\left.\left\{\left[\mathrm{A}+\mathrm{C}_{16} \mathrm{H}_{33}\right]-\right\} 2819.0892\right)$. IR (Nujol) $\vee \mathrm{cm}^{-1}: 2495(\mathrm{BH}), 2345(\mathrm{CN}), 1104$ (B-B-H). UVVis (THF) $\lambda_{\text {max }}(\lg \varepsilon) \mathrm{nm}: 422$ (5.21), 515 (4.21), 551 (4.10), 593 (3.78), $652(3.71) .{ }^{11} \mathrm{~B}-\left\{{ }^{1} \mathrm{H}\right\}$ NMR $\left(\mathrm{CD}_{2} \mathrm{Cl}_{2}\right) \delta$ ppm: -0.7 (d, 1B,
$\left.\mathrm{B}_{\mathrm{ap}}\right),-1.9\left(\mathrm{~d}, 1 \mathrm{~B}, \mathrm{~B}_{\mathrm{ap}}\right),-14.4\left(\mathrm{~s}, 2 \mathrm{~B}, \mathrm{~B}_{\mathrm{sub}}\right),-27.1(\mathrm{~d}, 4 \mathrm{~B}),-30.7$ (d, 3B). ${ }^{1} \mathrm{H}$ NMR $\left(\mathrm{CD}_{2} \mathrm{Cl}_{2}\right) \delta \mathrm{ppm}:-0.70-1.75\left(\mathrm{~m}, 8 \mathrm{H}, \mathrm{B}_{10} H_{8}\right), 10.73$ (br.s, $2 \mathrm{H}, \mathrm{CH}_{2} \mathrm{NH}$ ), 8,62 (br.s, $16 \mathrm{H}$, pyrrole), 8,17 (d, 16H, $o-\mathrm{Ph}$ ), $7.60(\mathrm{~m}, 16 \mathrm{H}, m-\mathrm{Ph}), 5.95$ (br.s, $2 \mathrm{H}, \mathrm{NH}=\mathrm{C}), 4.37$ (t, 16H, $\mathrm{OCH}_{2}$ ), $3,72\left(\mathrm{~m}, 4 \mathrm{H}, \mathrm{CH}_{2} \mathrm{NH}\right), 2.28$ (s. $\left.6 \mathrm{H}, \mathrm{CH}_{3}\right), 2.07$ (m, 8H, $\mathrm{OCH}_{2} \mathrm{CH}_{2}$ $\left.\mathrm{CH}_{2} \mathrm{CH}_{2} \mathrm{NH}_{2}\right), 1.86\left(\mathrm{~m}, 12 \mathrm{H}, \mathrm{OCH}_{2} \mathrm{CH}_{2}\right), 1.60-1.20(\mathrm{~m}, 156 \mathrm{H}$, $\left.\left(\mathrm{CH}_{2}\right)_{13}\right), 1.04$ (t, 18H, $\left.\mathrm{CH}_{3}\right),-1.41$ (br.s, $\left.4 \mathrm{H}, \mathrm{NH}\right)$.

\section{Results and Discussion}

First, approach to the synthesis of porphyrins with pendant amino groups was developed. ${ }^{[9]}$ Primary amines can be obtained from the corresponding halides by reaction with potassium phthalimide followed by removal of the phthalimide protection and the formation of an amino group. In case of porphyrins such synthesis is generally carried out in DMF using an excess of potassium phthalimide. ${ }^{[10]}$ However, the target porphyrins with three long chain alkoxy residues cannot be obtain by such approach, since the corresponding bromine-containing porphyrins are insoluble in DMF, and other organic solvents do not dissolve potassium phthalimide. Conducting this reaction in heterophase conditions has resulted in very low yields. Therefore, we proposed an alternative approach: $p$-hydroxybenzaldehyde was alkylated with appropriate dibromoalkanes in the presence of DBU in THF, using a 1.3-fold excess of dibromalkane to minimize the formation of a side disubstituted product (dialdehyde) to produce 4-(4-bromobutyloxy)benzaldehyde 1 (Scheme 1). The product was purified by column chromatography, yield was about $50 \%$. In the next step, benzaldehyde $\mathbf{1}$ was boiled in with 1.5 excess of potassium phthalimide in argon flow. After column chromatography the yield was about $90 \%$.

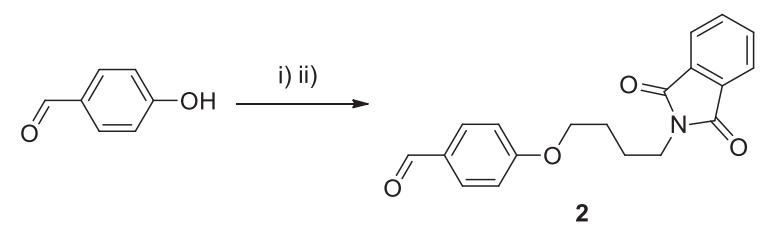

Reagents and conditions: i) $-\mathrm{Br}\left(\mathrm{CH}_{2}\right)_{4} \mathrm{Br}$, THF, DBU; ii) - Potassium phthalimide, DMF, argon.

Scheme 1.

Synthesis of unsymmetrical porphyrin 5 was carried out via a Lewis acid catalyzed mixed aldehyde condensation of $p$-(4-phthalimidebutyloxy)benzaldehyde $\mathbf{2}$, $p$-(hexadecyloxy)benzaldehyde $\mathbf{3}$ and pyrrole under standard Lindsey condition in $12 \%$ yield (Scheme 2). ${ }^{[1]}$ The deprotection of phthalimide was carried out by successive alkaline and acid hydrolysis. ${ }^{[12]}$ Phthalimide-containing porphyrin was dissolved in a mixture of dioxane-methanol-water (6:1:1) and an aqueous solution of sodium hydroxide $(0.5 \mathrm{M})$ was added, mixture was boiled $1 \mathrm{~h}$ and after this it was immediately evaporated. At the acid hydrolysis stage, porphyrin was dissolved in a minimum amount of $70 \%$ sulfuric acid and boiled for 4 hours. The target compound $\mathbf{5}$ was extracted with ethyl acetate with neutralization of an aqueous phase.

It is known that nitrilium derivatives of closo-decaborate anion $\left[2-\mathrm{B}_{10} \mathrm{H}_{9} \mathrm{~N} \equiv \mathrm{CMe}\right]^{-}$have high reactivity in reac- 


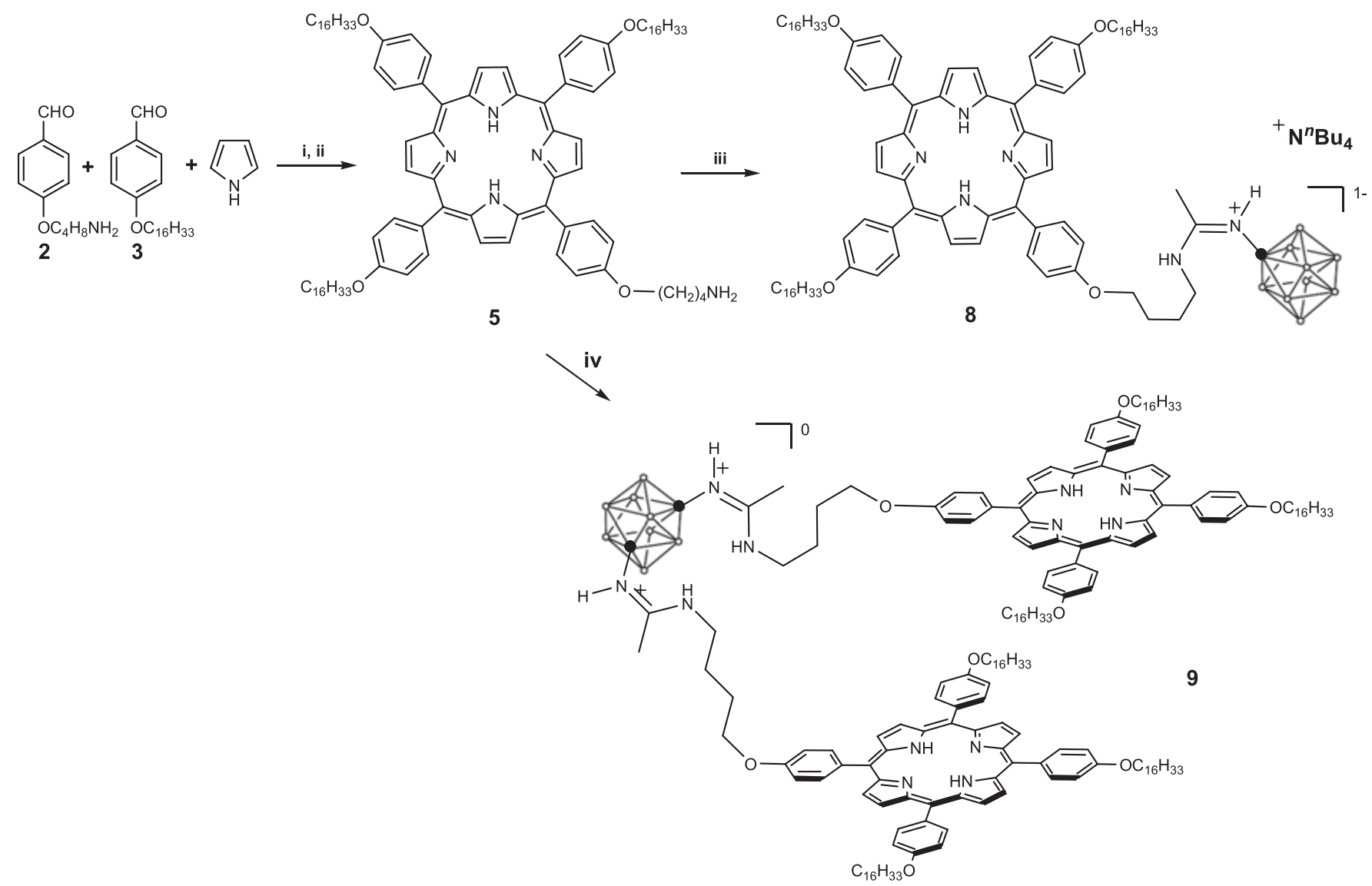

Reagents and conditions: $\left.\mathrm{i}-1) \mathrm{BF}_{3} \cdot \mathrm{OEt}_{2}, \mathrm{CHCl}_{3}, 2\right) \mathrm{DDQ}$; ii - Potassium phthalimide, DMF, argon; iii - $\left(\mathrm{N}^{n} \mathrm{Bu}_{4}\right)\left[2-\mathrm{B}_{10} \mathrm{H}_{9} \mathrm{NCCH}_{3}\right](6), \mathrm{C}_{2} \mathrm{H}_{4} \mathrm{Cl}_{2}$; iv $-\left[2,7-\mathrm{B}_{10} \mathrm{H}_{8}\left(\mathrm{NCCH}_{3}\right)_{2}\right](7), \mathrm{MeCN} / \mathrm{CH}_{2} \mathrm{Cl}_{2}$, Microwave.

Scheme 2.

tion of nucleophilic addition and [2+3] cycloaddition reactions. ${ }^{[13-18]}$ Previously we discovered convenient method of synthesis of disubstituted oxonium derivatives using $\mathrm{CF}_{3} \mathrm{SO}_{3} \mathrm{H}$ as electrophilic inductor. ${ }^{[19]}$ This method is quite universal and allows to produce disubstituted derivatives containing various exo-polyhedral bonds. In our case we tried to obtain closo-decaborate derivatives with two nitrilium groups. Interaction between anion $\left[\mathrm{B}_{10} \mathrm{H}_{10}\right]^{2-}$ and acetonitrile in presence of 3 equivalents of $\mathrm{CF}_{3} \mathrm{SO}_{3} \mathrm{H}$ was conducted in pure acetonitrile, under heating at $70{ }^{\circ} \mathrm{C}$. On the basis of data from the ${ }^{11} \mathrm{~B}$ NMR spectra, two regioisomers 2,6and $\left[2,7-\mathrm{B}_{10} \mathrm{H}_{8}\left(\mathrm{NCCH}_{3}\right)_{2}\right]^{0}$ (7) were formed in the ratio of 1:4. Separation of the two regioisomers was a difficult task. Chromatography of the regioisomers failed (retention times of two regioisomers are equal), so it is possible only to reduce the amount of 2,6-isomer in the initial mixture. In our case we decided to use the mixture of two regioisomers and then purify final amidine.

Two boron-porphyrin conjugates 8,9 were synthesized based on the reaction of nucleophilic addition of the aminosubstituted porphyrins to mono- and dinitrilium derivatives of $\left[\mathrm{B}_{10} \mathrm{H}_{10}\right]^{2-}$ anion (Scheme 2). In the case of anion $\left[2-\mathrm{B}_{10} \mathrm{H}_{9} \mathrm{NCCH}_{3}\right]^{-6}$ the process takes place under the following conditions $\left(70{ }^{\circ} \mathrm{C}, \mathrm{C}_{2} \mathrm{H}_{4} \mathrm{Cl}_{2}\right)$, the yield of boron is close to quantitative (according to ${ }^{11} \mathrm{~B}$ NMR spectrum). Full conversion of the original nitrilium derivative was observed for $8 \mathrm{~h}$. Dinitrilium derivative of closo-decaborate 7 is less reactive, so the process of addition takes much longer time. System for microwave synthesis was used to reduce the reaction time. Carrying out the reaction in microwave system the reaction time was decreased and the yield of product 9 with two porphyrin fragments was also increased. It is worth noting that conjugate 9 has a meta-arrangement of substituents in the boron cluster $\left.\left[2,7-\mathrm{B}_{10} \mathrm{H}_{8} \text { (amidine }\right)_{2}\right]$. This is probably due to steric factors.

All conjugates were characterized by TLC, UV-Vis and ${ }^{1} \mathrm{H},{ }^{11} \mathrm{~B}$ NMR spectroscopy, ESI-MS mass-spectrometry. Figure 1 shows UV-Vis and fluorescence spectra of compounds $\mathbf{5}, \mathbf{8}, \mathbf{9}$. As we assumed absorbance and fluorescence intensity of conjugate $\mathbf{9}$ was higher compared to the porphyrin $\mathbf{5}$ and conjugate $\mathbf{8}$ because of two dye moieties. Also, fluorescence spectra of both conjugates are red shifted $(14 \mathrm{~nm})$ compared with starting aminoporphyrin. It can be explained by interactions between porphyrin and closo-decaborate fragment.

\section{Conclusions}

In this work we have elaborated a convenient approach to the synthesis of aminoporphyrins with pendant amino groups. Conjugates based on this compounds with boron anions $\left[\mathrm{B}_{10} \mathrm{H}_{10}\right]^{2-}$ were received. In such conjugates we varied amounts of porphyrin moiety (one or two). In first time boron- 


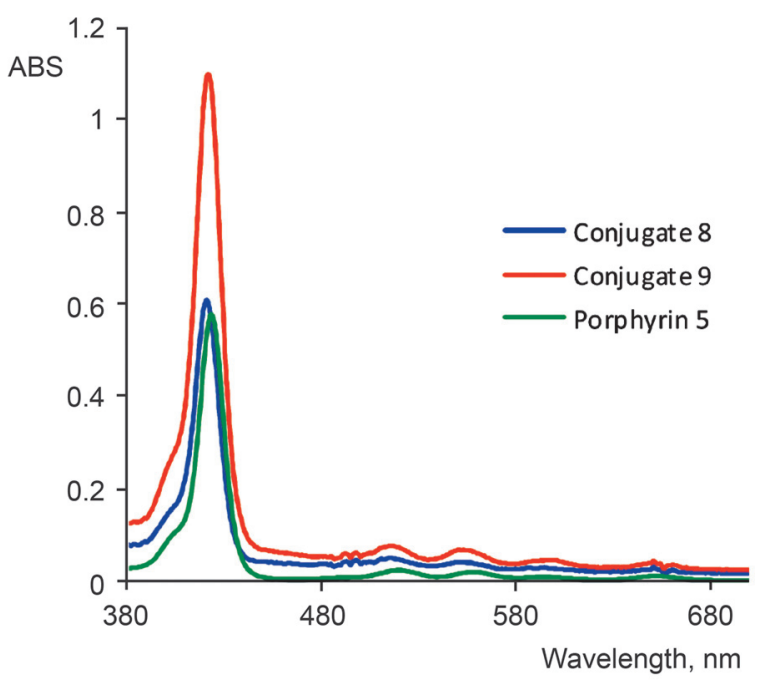

Figure 1a. UV-Vis spectra of 5, 8, 9 in THF $\left(C=1.5 \cdot 10^{-6} \mathrm{M}\right)$.

porphyrin conjugates were synthesized using microwaveassisted method. Such procedure reduces a time of reaction in two folds. Spectral characteristics of the conjugates were observed by electron absorption spectra and steady-state fluorescence.

Acknowledgements. The synthesis of aminoporphyrins was supported by the Russian Science Foundation (grant 16-13-10092). The synthesis of boron clusters and boronporphyrin conjugates was supported by the Russian Foundation of Basic Research, project № 16-03-01039 and the Presidential Grant Program MK-4654.2016.3.

\section{References}

1. Bregadze V.I., Sivaev I.B., Lobanova I.A., Titeev R.A., Brittal D.I., Grin M.A., Mironov A.F. Appl. Radiat. Isot. 2009, 67, 101-104.

2. Hiramatsu R., Kawabata S., Miyatake S.-I., Kuroiwa T., Easson M.W., Vicente M.G.H. Lasers Surg. Med. 2011, 43(1), 52-58.

3. Barth R.F., Vicente M.G.H., Harling O.K., Kiger III W.S., Riley K.J., Binns P.J., Wagner F.M., Suzuki M., Aihara T., Kato I., Kawabata S. Radiat Oncol. 2012, 7, 146.

4. Sibrian-Vazquez M., Vicente M.G.H. In: Boron Science: New Technologies and Applications (Hosmane N.S., Ed.). Boca Raton: CRC, 2011. p. 203-232.

5. Sivaev I.B., Bregadze V.V. Eur. J. Inorg. Chem. 2009, 11, $1433-1450$.

6. Zhdanova K.A., Zhdanov A.P., Ezhov A.V., Fakhrutdinov A.N., Bragina N.A., Zhizhin K.Yu., Kuznetsov N.T., Mironov A.F. Macroheterocycles 2014, 7, 394-400.

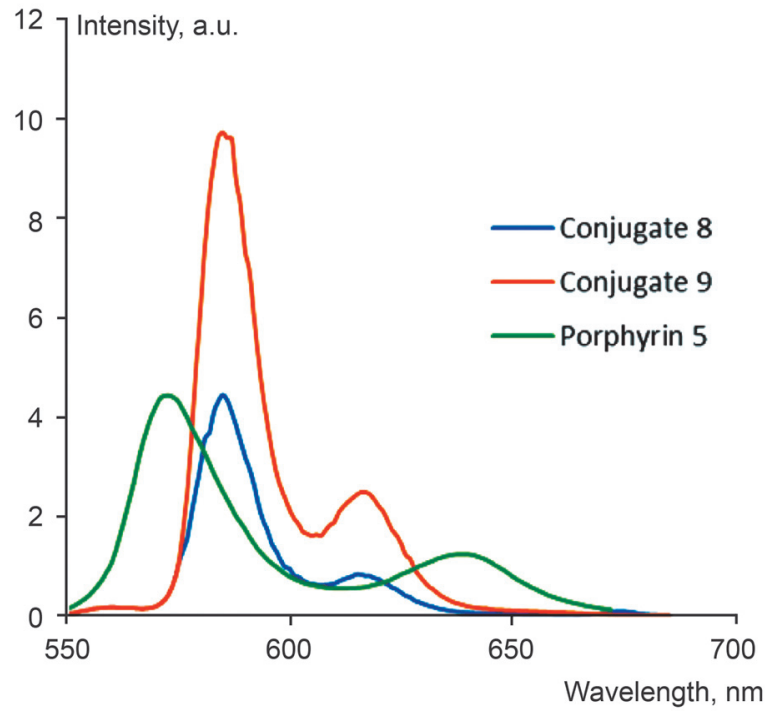

Figure 1b. Fluorescence spectra of 5, 8, 9 in $\operatorname{THF}\left(\lambda_{\mathrm{ex}}=420 \mathrm{~nm}\right)$.

7. Zhdanova K.A., Zhdanov A.P., Ezhov A.V., Bragina N.A., Zhizhin K.Yu., Ushakova I.P., Mironov A.F., Kuznetsov N.T. Russ. Chem. Bull. 2014, 1, 194-200.

8. Fedulova I.N., Novikov N.V., Ugol'nikova O.A., Bragina N.A., Ushakova I.P., Mironov A.F. Vestnik MITHT 2007, 2(4), 83-89.

9. Gibson M.S., Bradshaw R.W. Angew. Chem. Int. Ed. 1968, 7, 919-930.

10. Milgrom L.R., O’Neil F. Tetrahedron 1995, 51, 2137-2144.

11. Lindsey J.S., Hsu H.C., Schreiman I.C. Tetrahedron Lett. 1986, 27, 4969-4970.

12. Lavallee D.K., Xu Z., Pina R. J. Org. Chem. 1993, 58, 60006008.

13. Zhdanov A.P., Lisovsky M.V., Goeva L.V., Razgonyaeva G.A., Polyakova I.N., Zhizhin K.Y., Kuznetsov N.T. Russ. Chem. Bull. 2009, 58, 1694-1700.

14. Zhdanov A.P., Polyakova I.N., Razgonyaeva G.A., Zhizhin K.Y., Kuznetsov N.T. Russ. J. Inorg. Chem. 2011, 56, 847-855.

15. Mindich A.L., Bokach N.A., Kuznetsov M.L., Haukka M., Zhdanov A.P., Zhizhin K.Y., Miltsov S.A., Kuznetsov N.T., Kukushkin V.Y. ChemPlusChem 2012, 77, 1075-1086.

16. Bolotin D.S., Burianova V.K., Novikov A.S., Demakova M.Y., Pretorius C., Mokolokolo P.P., Roodt A., Bokach N.A., Suslonov V.V., Zhdanov A.P., Zhizhin K.Y., Kuznetsov N.T., Kukushkin V.Y. Organometallics 2016, 35, 3612-3623.

17. Mindich A.L., Bokach N.A., Dolgushin F.M., Haukka M., Lisitsyn L.A., Zhdanov A.P., Zhizhin K.Y., Miltsov S.A., Kuznetsov N.T., Kukushkin V.Y. Organometallics 2012, 31, 1716-1724.

18. Mindich A.L., Bokach N.A., Kuznetsov M.L., Starova G.L., Zhdanov A.P., Zhizhin K.Y., Miltsov S.A., Kuznetsov N.T., Kukushkin V.Y. Organometallics 2013, 32, 6576-6586.

19. Klyukin I.N., Kubasov A.S., Limarev I.P., Zhdanov A.P., Matveev E.Y., Polyakova I.N., Zhizhin K.Y., Kuznetsov N.T. Polyhedron 2015, 101, 215-222. 